\title{
Uludağ' da Faaliyet Gösteren 4 ve 5 Yıldızlı Konaklama İşletmelerinin Çevrimiçi Tüketici Yorumlarının İncelenmesi: “TripAdvisor.com" Üzerinden İçerik Analizi
}

DOI: 10.26466/opus.780219

\author{
Azize Rana Arkadaș* - Tuğrul Ayyıldız ** \\ *Yüksek Lisans Öğrencisi, Adnan Menderes Üniversitesi, Turizm Fakültesi, Aydın/Türkiye \\ E-Posta: rana.arkadas@hotmail.com \\ ORCID: 0000-0002-1603-3232 \\ ** Dr. Öğretim Üyesi, Adnan Menderes Üniversitesi, Turizm Fakültesi, Aydın/Türkiye \\ E-Posta: tugrulayyildiz@gmail.com \\ ORCID: $\underline{0000-0001-6332-975 X}$
}

\begin{abstract}
Öz
Günümüzde insanlar bir turistik ürün satın almaya karar verirken birden çok web platformlarında yer alan çevrimiçi yorumlara bakmaktadır. Aynı zamanda, önceden seyahat süresince deneyimlenmiş davranışlardan gelen geri bildirimlere bakarak turistik ürün satın almak isteyen insanların bu gibi yorumları inceleme oranlarının gün geçtikçe arttığı bilinmektedir. Çevrimiçi yapılan bu tüketici yorumları, birçok insanı sosyal bir ă̆ üzerinden ortak paylaşım platformlarında buluşturmaktadır. Ayrıca günümüzde turistik ürünü satın aldıktan sonra birçok tüketici seyahatlerini ve deneyimlerini fotoğrafçekerek kayıt altına almaktadır. Kayıt altına alınan bu fotoğrafların ortak paylaşım platformlarına yüklenmesi ve herkes ile paylaşılması sonucunda yeni bir turistik ürün alacak kişiler bu platformlardaki yorumlara bakmaktadırlar. Bu çevrimiçi tüketici yorumları, turistik ürünü alacak kişilerin inceleme yapması sonucunda karar verme ve satın alma davranışların etkilemekte ve değgistirmektedir. Bu çalışmada, Tripadvisor.com web sitesi aracılı̆̆ıla Uludağ'da bulunan 4 ve 5 yildızl konaklama işletmeleri ile ilgili yazılan olumsuz yorumlar belirlenmiş ve incelenen yorumlar içerik analizinden yararlanılarak değerlendirilmiştir. Çalışmadaki işletmeler hakkında yazılan olumsuz yorumlar doğrultusunda çeşitli kriterler belirlenmiş ve sorunları önlenmesine yönelik öneriler getirilmiştir.
\end{abstract}

Anahtar Kelimeler: Çevrimiçi Tüketici Yorumları, Turistik Ürün, Konaklama İşletmeleri, İçerik Analizi 


\title{
Investigation of Online Consumer Reviews of 4 and 5 Star Accommodation Enterprises Operating in Uludağ: A Content Analysis on "TripAdvisor.com"
}

\begin{abstract}
Nowadays, people look at online consumer reviews on multiple web platforms when deciding to buy a tourism product. At the same time, it is known that the rate of people who want to buy tourism products by looking at the feedback from the behaviors experienced during the travels is increasing day by day. These online consumer reviews bring many people together on common sharing platforms over a social network. In addition, after buying the touristic product, many consumers record their travels and experiences by taking photos. Sharing the recorded photos with everyone will be beneficial for those who will buy new touristic products. These online consumer reviews influence and change the decision-making and purchasing behavior of tourist buyers as a result of the review. In this case, the negative reviews about the 4 and 5 star hotels in Uludağ were determined through the website of Tripadvisor.com and the investigated reviews were evaluated using the content analysis. In line with the negative comments written about the enterprises in the study, criteria have been determined and suggestions have been made to prevent problems.
\end{abstract}

Keywords: Online Consumer Reviews, Touristic Product, Accommodation Enterprises, Content Analysis 


\section{Giriş}

Değişen rekabet koşulları, yeni tüketici davranış biçimleri ve özellikle web tabanlı sistemler, mevcut otelcilik pazarında yeni modelleri ve büyümeyi beraberinde getirmektedir. Web 2.0 araçları, satın alma, satış, ödeme, göz atma, yayınlama, bireylerin paylaşım yapmalarını sağlayan çok çeşitli web sitelerine ve uygulamalara sahip olarak kullanıciların hayatını kolaylaştırmaktadır. Web 2.0 araçları, bireyleri bir sosyal katılım ağı ve bilgi paylaşımı ağı üzerinden buluşturma uygulamalarını ifade etmektedir. Web 2.0 tanımı "Kullanuclarm iş ve sosyal süreçlerde katılımcı olarak deneyimlerini, bilgilerini ve pazar gücünü artıran açık kaynaklı, etkileşimli ve kullanıcı kontrollü çevrimiçi uygulamaların bir koleksiyonudur." (Constantinides ve J.Fountain, 2008, s. 232). Web 2.0 olarak adlandırılan bu araçlar "Tripadvisor, Booking, Lonely Planet, Flickr, bloglar ve diğer çevrimiçi sosyal ağ siteleri vb." olarak ifade edilmektedir. İnteraktif internet kullanıcılarının içerik oluşturmasına, bilgi paylaşımına, bilgi üretmek ve tüketmek konusunda büyük bir olanak sağlamaktadır (Almeida, 2012).

Son zamanlarda, internet kullanıc sayısınin artması ile web 2.0 aracilığıyla insanlar, interneti bir pazarlama ve bilgi iletişim aracı olarak kullanmaktadır (Chui, 2010). Web tabanını kısıtlı kullanan kuruluşlara oranla rekabetçi pazar ortamında web tabanlı organizasyon yürüten kuruluşların artık daha başarılı olduğu bir gerçektir. Gartner'ın yaptığı anket çalışmalarında ise kuruluşlarının yarısının IT işlemleri için Web 2.0 tanıtım araçlarını kullandığını ortaya koymaktadır (Almeida, 2012). Bughin ve Chui (2010) 'e göre "Web 2.0, bireyler ve kuruluşlar, müşteriler ve tedarikçiler arasındaki etkileşimi güçlendirmektedir". Dünyanın ilk yönetim danışmanlığı ünvanına sahip olan kişisi Mc Kinsey'in, web 2.0 teknolojilerinin kullanımına ilişkin yaptığı ankette yüksek kar marjları kazanıldığını ortaya koymaktadır. Web 2.0 kullanan 3.249 yöneticiye yönelik yapılan anket araştırmasında sosyal ağ kullanımının \%40 ve aktif blog kullanımının \%38 şeklinde olduğunu ortaya koymuştur. Araştırmanın yapıldığı kuruluşlarda Web 2.0 kullananların pazar payı, faaliyet karları ve pazar liderliklerinin her geçen yıl daha da arttırdıkları belirtilmektedir (Chui, 2010).

Ürünü sunduğu pazar ile hem sözel hem de görsel bilgiyi eş zamanlı olarak sunarak, müşterilerinin ihtiyaçlarını ve görüşlerini öğrenmek, onlarla doğrudan ve kişiselleştirilmiş bir şekilde etkileşim kurmak için yeni fursatlar 
sunmaktadır. Ayrıca kullanıcıların deneyimlerini sürekli bilgi olarak paylaşması üretkenlik ve güncelliği sağlamaktadır. İnternet sayesinde tüketiciler görüşlerini özgürce kullanıcı topluluklarına sunabilmektedir (Gretzel ve Yoo, 2008). Bu web tabanlı platformla aynı zamanda hizmet veren kuruluşlar için yapmaları gereken iyileştirmeler için bir geri bildirim kaynağı oluşturmaktadır. Turizm endüstrisinde her geçen gün konaklama işletmeleri ve turizm işletme rakamlarının sayısı artmaktadır. Müşterinin vereceği mevcut kararı değiştirmede e-WOM ve web tabanlı iletişim araçları büyük bir rol oynamaktadır. Son zamanlarda Web 2.0 teknolojilerini sık kullanımı turizm talep ve arzına ayrıca konaklama işletmelerine önemli ölçüde katkıda bulunmaktadır. Seyahat tüketicileri, konaklama işletmelerinin somut olmayan ürün ve hizmetlerini satın alırken diğer bireylerin görüşlerine bağımlı hareket etmektedirler. Bu nedenle işletmelerin de seyahat tüketicilerini olumlu içerik paylaşımına teşvik etmesi gerekmektedir. Bu durum pazarlama yelpazesini genişletebildiği gibi maliyetlerini en aza indirgemesine katkıda bulunacaktır.

İnternete olan güvenin artması, seyahat tüketicisinin seçim algısını değiştirmektedir. Böylelikle e-WOM hakkında daha çok araştırma yapma ihtiyacı belirmektedir. Seyahat tüketicilerinin davranış ve tutumlarının şekillenmesi e-WOM'da birçok yolla gerçekleşebilmektedir. Bunlardan bazıları, web tabanlı görüş platformları, tartışma forumları, boykot Web siteleri olarak örnek verilebilir. Pazarlamacılar, tüketicilerin tutum ve davranışlarını etkilemek için kasıtlı olarak viral pazarlama, viral reklamclık ve çevrimiçi referanslar gibi çeşitli e-WOM türleri başlatmışlardır (Wang ve Rodgers, 2011). Kullanıcı odaklı içerik (UGC; user generated content), Tüketici tarafından oluşturulan içerik (CGC; consumer generated content) gezginlerin seyahat ile ilgili planlama aşamasında internet artık bir bilgi kaynağı olarak sunulmaktadır (Gretzel ve Yoo, 2008). Gelenekselleşmiş olan medyanın tersine, İnternet'teki profesyoneller tarafından oluşturulmayan veya yayınlanmayan içeriği ifade etmektedirler. UGC; blog, web sitesi, resimler, sosyal medya gönderileri ve referanslar da dahil olmak üzere her tür içerik sayılmaktadır. Tüketicilerin ürünleri veya hizmetleri İnternet'teki diğer tüketicilere yönlendirdiği durumlar için tasarlanan e-WOM, UGC ve CGC ile aynı pazarlamaya eşit sayılmaktadır (Wang ve Rodgers, 2011); (Carmen, Burgess, Buultjens, ve Cox, 2009). Epazarlamanın bir türü olan bu Web 2.0 siteleri tüketiciden tüketiciye deneyim akışını sağlamaktadır (Carmen, Burgess, Buultjens, ve Cox, 2009). Ancak, bu çalışmada e-WOM'a yönelik bilgiler ışığında içerik analiz yapılmaktadır. 
Web tabanlı tartışma panoları, çevrimiçi topluluklar ve sosyal ağ siteleri, e-WOM reklamcilığı için bireylere daha güvenilir bir ortam oluşturmaktadır. Ticari gruplar veya şirketler için, e-WOM'u değiştirmek veya etkilemek pazarlama için yeni firsatlar yaratmaktadır (Wang ve Rodgers, 2011). Yani sosyal medyadaki e-WOM, önemli bir e-WOM türüdür. Örnek olarak; birey tatilden döndükten sonra, kişisel deneyimlerini çevrimiçi sosyal ağ sitelerinde (instagram, facebook vb.) arkadaşlarıyla paylaşmak istemektedir. Tatil yaptıkları otel, yemek yediği restoranlar, katıldıkları etkinlikler gibi birçok deneyiminin fotoğrafların paylaşmakta ve seyahatlerinin ayrıntıları hakkında konuşmaktadırlar. Bunun dişında bilgilendirici e-WOM, otelin ne kadar temiz olduğunu, personelin nazik olup olmadığını, yüzme havuzunu beğenip beğenmediklerini vb. tarafsız yorumlarla tüketici değerlendirme siteleri ve Tripadvisor gibi web sitelerinde de konaklama işletmeleri hakkında tavsiyelerde bulunmaktadırlar.

Konaklama işletmelerinin tüketicilere sunduğu hizmetlerin pek çok unsurdan meydana gelmesi misafir memnuniyetini oluşturan kriterleri değiştirmektedir. Misafir memnuniyeti pratikte çok göreceli bir kavramdır. Kullanıc yorumlarının incelenmesi ile misafir deneyimlerini oluşturan yeni tüketici davranış biçimleri takip edilebilecek ve güncel kalınabilecektir. Tripadvisor sitesindeki seyahat tüketicilerinin yorumları doğrultusunda olumsuz yorumların incelenmesi bu alana önemli bir katkı sağlayacaktır.

Bu çalışmada, Uludağ'da faaliyet gösteren 4 ve 5 yıldızlı konaklama işletmeleri ve kullanıcıların turistik ürün ve hizmetlerle ilgili deneyimlerini ve görüşlerini paylaştığı sosyal ağ platformlardan birisi olan "Tripadvisor" web sitesindeki konaklama işletmeleriyle ilgili düşük puan almış İngilizce ve Türkçe yorumlara içerik analizi yapılarak yerli ve yabancı turistlerin bu işletmelerle ilgili olumsuz görüşleri incelenmiştir. Çalışma ile ilgili örneklemde yer alan işletmelerin 8 farklı temel kriter üzerinden değerlendirmesi yapılarak bu boyutlar üzerinden öne çıkan boyutların neler olduğu belirlenmiştir.

\section{Seyahat Tüketicilerinin Otel Seçiminde Kriterleri}

Yapılan literatür taraması sonucunda otel deneyimlerini içeren araştırmalarda 10 adet çalışma incelenmiştir. Genel olarak kabul edilen beş otel boyutunun; hizmet kalitesi, otelin konumu ve imkanları, personel, yönetsel sorunlar, faturalandırma oluşturduğu görülmüştür ve bu bağlamda konuyla ilgili 
çalışmaların detayları Tablo 1'de özet olarak aktarılmıştır. Verilen bu beş boyutun yanı sira; odalar, restoran, rezervasyon ve resepsiyon, müşteri hizmetleri gibi boyutların otel deneyimlerini etkileyen önemli boyutlar olduğu anlaşılmıştır. Bu çalışmada ise otel seçim kriteri literatürde yer alan 8 kriter dikkate alınarak inceleme konusu yapılmıştır. Bu kriterler; “odalar, yiyecek-içecek, personel, fiyat/fayda, atmosfer, yönetim, hizmet, otelin özellik ve imkanları" şeklindedir.

Tablo 1. Konaklama işletmelerinin Değerlendirildiği Kriterlere İlişkin Çalışmalar

\begin{tabular}{|c|c|c|c|}
\hline Yazar adı & Yayıl yılı & Çalışmanın Konusu & $\begin{array}{l}\text { Otel işletmelerinin kriterlerine } \\
\text { yönelik bulgular }\end{array}$ \\
\hline $\begin{array}{l}\text { Osman Çulha., } \\
\text { Güngör Hacıoğlu., } \\
\text { Gizem KURT. }\end{array}$ & 2009 & $\begin{array}{l}\text { Bu araştırmanın temel amacı, } \\
\text { internet şikâyet sitelerinde yer } \\
\text { alan konaklama işletmelerine } \\
\text { yönelik müş̧teri } \\
\text { Şikâyetlerinin hangi kategori- } \\
\text { ler altında toplandığını belirle- } \\
\text { mek ve bu sayede yazına ve } \\
\text { uygulayıcılara katkıda } \\
\text { bulunmak. }\end{array}$ & $\begin{array}{l}8 \text { temel kategoriye ayrılmıştır; } \\
\text { odalar, restoran, yiyecek-içecek, iş gö- } \\
\text { ren ile ilgili şikayetler, rezervasyon- } \\
\text { resepsiyon, yönetim politikası, müş- } \\
\text { teri hizmetleri, otelin özellik ve im- } \\
\text { kanları. }\end{array}$ \\
\hline $\begin{array}{l}\text { Tianshu Zheng., } \\
\text { Hyewon Youn., } \\
\text { Clark S. Kincaid }\end{array}$ & 2009 & $\begin{array}{l}\text { Çalışmada ABD'nin güneyba- } \\
\text { tısından popüler bir destinas- } \\
\text { yondan altı lüks otel seçilmiş. } \\
\text { Tripadvisor sitesi aracılığı ile } \\
\text { olumsuz yorumlar belirlen- } \\
\text { miş. Burada konaklama orga- } \\
\text { nizasyon algıları ve müşteri şi- } \\
\text { kayetleri incelenmiş. }\end{array}$ & $\begin{array}{l}\text { Çalışmada } 504 \text { yorum } 5 \text { katego- } \\
\text { riye ayrılmış; oda, hizmet, değer, te- } \\
\text { mizlik ve yemek 'hizmet" hakkın- } \\
\text { daki yorumların anlaşılabilmesi } \\
\text { için sekiz alt kategoriye ayrılmış- } \\
\text { tır; oda rezervasyonu, personeller, fa- } \\
\text { turalandırma, beklenen isteklerin } \\
\text { karşılanmamasl, isteklere cevap ver- } \\
\text { meme, yanıltıcı tutundurma, hizmet } \\
\text { gecikmesi }\end{array}$ \\
\hline $\begin{array}{l}\text { Beverley A. Sparks., } \\
\text { Victoria Browning. }\end{array}$ & 2010 & $\begin{array}{l}\text { Bu çalışma internete yayılmış } \\
\text { olumsuz yorumları inceleye- } \\
\text { rek çevrimiçi tüketicilerinin } \\
\text { doğası hakkında. }\end{array}$ & $\begin{array}{l}\text { Şikayetlerin odak noktasında be- } \\
\text { lirlenen kriterler şöyledir; odanın } \\
\text { özelliği, servis kalitesi, yiyecek ve içe- } \\
\text { cek, otelin konum ve imkanları, tüke- } \\
\text { tici hizmetleri (personeller, yönetim } \\
\text { politikası). }\end{array}$ \\
\hline $\begin{array}{l}\text { Stuart E. Levy., } \\
\text { Wenjing Duan. and } \\
\text { Soyoung Boo. }\end{array}$ & 2012 & $\begin{array}{l}\text { Dünya'nın otel başkenti ola- } \\
\text { rak ilan edilen Washington } \\
\text { D.C örnek bir pazar olarak ko- } \\
\text { naklama endüstrisinin tek yıl- } \\
\text { dızlı çevrimiçi yorumların in- } \\
\text { celenmesi ve otel özelliklerinin } \\
\text { müşteri şikayetlerini nasıl et- } \\
\text { kilediği. }\end{array}$ & $\begin{array}{l}\text { İncelemeler } 13 \text { kriter belirlenmiş- } \\
\text { tir; ön büro personelleri, banyo, park } \\
\text { etme, check-in, temizlik, gürültü̈, fa- } \\
\text { turalandırma, odalar, housekeeping } \\
\text { personeli, restaurant, atmosfer, } \\
\text { wifi'dir. }\end{array}$ \\
\hline
\end{tabular}




\begin{tabular}{lll}
\hline Güney Çetin Gürkan., 2014 & Ege ve Akdeniz Bölgesi'nde \\
Dilek Dönmez Polat. & & Faaliyet Gösteren Resort Ko- \\
& naklama \\
& İşletmeleri Hakkında Yapılan \\
& Şikayetler Üzerine Nitel Bir \\
& Araştırma
\end{tabular}

\begin{tabular}{lll}
\hline Catheryn Khoo-Latti- & 2014 & Malezya, Kuala Lumpur'daki \\
more., Faranak & & 4 ve5 yıldızlı lüks otellerde ko- \\
Memarzadeh., & & naklayan müşterilerin inter- \\
Erdoğan Ekiz. & & nete bıraktığ şikayetleri araş- \\
& tırmak.
\end{tabular}

\begin{tabular}{|c|c|c|}
\hline $\begin{array}{l}\text { Mustafeed Zaman., } \\
\text { Laurent Botti., } \\
\text { Tan Vo Thanh., }\end{array}$ & 2015 & $\begin{array}{l}\text { Potansiyel seyahat tüketicileri- } \\
\text { nin otel seçerken karar alma } \\
\text { sürecinde seçim ölçütlerin } \\
\text { ağırlı̆ı ile ilgili Tripadvisor } \\
\text { kriterlerine dayanan ampirik } \\
\text { bir çalışma. }\end{array}$ \\
\hline $\begin{array}{l}\text { Zaid } \\
\text { ALRAWADIEH., } \\
\text { Şehnaz Demirkol. }\end{array}$ & 2015 & $\begin{array}{l}\text { İstanbul'da bulunan beş yıl- } \\
\text { dızlı otellere yönelik şikâyet- } \\
\text { leri belirtmek. Bununla bir- } \\
\text { likte alt amaçlara ulaşmak. }\end{array}$ \\
\hline
\end{tabular}

\begin{tabular}{|c|c|c|c|}
\hline & & & gulanan politikalardır. \\
\hline $\begin{array}{l}\text { Mehmet Erhan } \\
\text { SUMMAK., } \\
\text { Halil SUNAR., } \\
\text { Mustafa } \\
\text { COŞKUNER. }\end{array}$ & 2017 & $\begin{array}{l}\text { Analitik Hiyerarşi Sureci } \\
\text { (AHS) yöntemini kullanmak } \\
\text { suretiyle tatil } \\
\text { amaçlı Antalya Lara Kundu } \\
\text { bölgesinde bulunan otellerden } \\
\text { booking.com aracilğ̆ıla en } \\
\text { uygun olanı belirleme işlemi- } \\
\text { nin } \\
\text { yapılması. }\end{array}$ & $\begin{array}{l}\text { Otel seçimi için oluşturulan mo- } \\
\text { delde değerlendirme kriteri } 7 \text { kri- } \\
\text { tere ayrilmıstır. Bunlar; temizlik, } \\
\text { konfor, olanaklar, konum, çalışanlar, } \\
\text { fiyat/denge faydası, wifi olarak ay- } \\
\text { rlmıştır. }\end{array}$ \\
\hline Sait DOĞAN & 2017 & $\begin{array}{l}\text { Aksaray } \\
\text { ilinde yer alan 2-3-4 ve } 5 \text { yıl- } \\
\text { diza sahip otellerle ilgili boo- } \\
\text { king.com internet sitesinde } \\
\text { yer alan çevrimiçi yorum ve } \\
\text { puanlamaları } \\
\text { incelemek. }\end{array}$ & $\begin{array}{l}\text { Aksaray } \\
\text { ilinde bulunan ylldızlı otellere } \\
\text { yönelik değerlendirme kriterleri } \\
\text { incelendiğinde yüksek puana sa- } \\
\text { hip kriterlerin sırasiyla; temizlik, } \\
\text { rahatllk, çalı̧anlar, fiyat/fayda den- } \\
\text { gesi, olanaklar, konum ve ücretsiz } \\
\text { wifi olduğu görülmüştür. }\end{array}$ \\
\hline
\end{tabular}

Yapılan içerik analizi sonucu beş ana tema altında toplanmıştır. Bu ana temalar; hizmet kalitesine dair sorunlar, yönetsel sorunlar, tesise dair yetersizlikler, personelden kaynaklanan sorunlar ve havuza bağhl sorunlar.

Yapilan tematik analiz sonucunda 54 farklı tema arasindan stk kullanilanlar; odalar, personel, oda servisi, check-in, temizlik, aktivitelyardımo programlar, tesis imkanlar, faturalandirmadir.

Çoklu karar verme analizi kullanarak yapilan 6 adet ölçüt; yer, yatak kalitesi, konfor ve ekipman, hizmet, para değeri ve temizliktir.

Bu çalışma sürecinin sonunda şikayetler 10 başlık altında sinıflandırılmıştır. Bu başlıklar; hizmet kalitesi, tesislerin kalitesi ve temizliği, personel tutumu ve performansl, fiyatlarn yüksek olması, işletmenin fiziksel özellikleri (Tasarım, mevki), yoğun ve gürültülï ortam, yiyecek ve içecek kalitesi, misafirlerin özel isteklerin karşlanmamast, yaniltıcı tutundurma ve bilgiler, işletmede uygulanan politikalardir.

Otel seçimi için oluşturulan mokonfor, olanaklar, konum, calısanlar, fiyat/denge faydası, wifi olarak ay-

.

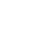




\section{e-WOM (Elektronik Ağıdan Ağıza İletişim) Kavramı}

WOM(ağızdan ağıza iletişim) üzerine pazarlama araştırması 1960'lı yıllara kadar dayanmaktadır. Eskiden beri ulusal ve uluslarası alanda birçok kez incelenmiş olan WOM "bir ürün, marka, organizasyon, kaynak veya etkinlik hakkında tüketicinin yaptığı yüz yüze informel iletişimin bireyin etkileme ve teşvik etme sürecidir" (Westbrook, 1987). WOM hakkında George Silverman kitabında uzmanların düşündüğünden daha güçlü bir pazarlama aracı olmasından bahsetmiştir. Silverman, WOM'un çağdaş pazarlamadaki durumunu "en eski ve en yeni pazarlama unsuru" olarak nitelendirmektedir. Silverman'a göre "WOM" sürecinin sadece insanlar konuştukları sürece var olduğunu ifade etmiştir (Silverman, 2011). İnternet ve mobil iletişim cihazlarının gelişimine paralel olarak insanların birbirleriyle bağlantı kurma yollarını kolaylaştırmış, sosyal ağların ve kişiler arası iletişim web tabanlı platformlara taşınmıştır. Bu süreçte "WOM" çağdaş pazarlamada artık "e-WOM" olarak adlandırılmaktadır.

Günümüzde seyahat tüketicileri bir ürünü satın almaya karar verdiklerinde bilinçli kararlar almak için incelemeler yapmaktadır. Seyahat seçenekleri hakkında; konaklama, ulaşım, restoranlar, turistik yerler ve özellikleri gibi kendi seyahat paketlerini oluşturmadan önce büyük miktarda bilgi toplaması gerekmektedir. Bu yüzden başkalarının daha önce deneyimlemiş oldukları bilgi ve hizmetlerden yararlanma gereksinimi duyarlar. e-WOM, çevrimiçi görüşler, web sitesi derecelendirmeleri, çevrimiçi geri bildirimler, incelemeler, yorumlar ve Internet'te deneyim paylaşımı gibi farklı şekillerde ifade edilebilmektedir. Yeni tüketici davranışı olarak kabul gören elektronik ağızdan ağıza iletişim (e-WOM) Harrison Walker (2001)'a göre " ticari-olarak algzlanmayan, bir mesaj gönderici ile mesaj ahıc arasında gerçekleşen bir marka, ürün, firma ya da hizmet ile ilgili resmi olmayan kişiden kişiye olan iletişim" olarak tanımlamaktadir.

Yeni bir küresel ağ iletişimi olan e-WOM seyahat planlaması için önemli dış bilgi kaynaklarından biri olarak kabul edilmektedir (Wang ve Rodgers, 2011). Pozitiflik ve negatiflik e-WOM'un iki önemli yönüdür, İlk e-WOM türü genellikle çevrimiçi geri bildirim sistemlerinde ve tüketici inceleme web sitelerinde üretilir. Bunlar, TripAdvisor.com gibi oteller ve tatiller için "tarafsız" incelemeler sunduğunu iddia eden üçüncü taraf inceleme web siteleri de bulunmaktadır. Çevrimiçi geri bildirim sistemleri ve inceleme web sitelerinin 
ana amacı bilgi sağlamaktır. Son zamanlarda yapılan birkaç çalışma, çevrimiçi incelemelerin müş̧teri satın alma niyetleri üzerindeki derin etkileri konusunda fikir birliğindedir. e-WOM'un değeri literatürde iki yaklaşım kullanılarak ölçülmüştür. Birinci yaklaşım, kaç kişinin etkilendiği, ikinci yaklaşım ise nihai ve hızlı benimseyen fayda sağladığını varsaymaktadır (Mishra ve S.M.Satish, 2016).

Tablo 2' de gösterildiği gibi WOM'un ürün üzerindeki etkisini ölçmek için çeşitli boyutlar dikkate alınarak analiz yapılabilmektedir (Mauri ve Minazzi, 2013).

Tablo 2. WOM'un Ürün Üzerindeki Etkisini Ölçmek İçin Gereken Boyutlar

\begin{tabular}{l}
\hline Değerlik (pozitif ve negatif) \\
\hline Yoğunluk (yorum miktarı) \\
\hline Hız (belirli bir zaman dilimindeki kişi sayısı) \\
\hline Kalıcilık (zaman uzunluğu) \\
\hline Önemi (yorumların müşsteri kararlarında rolü) \\
\hline Güvenilirlik (kaynağınn güvencesi ve güvencesi açısından mesaj). \\
\hline
\end{tabular}

\section{Konaklama ve Turizm Endüstrisinde e-WOM'un (Elektronik Ağızdan Ağıa İletişim) Satın Alma Sürecindeki Rolü}

Konaklama işletmeleri ve turizm pazarlamaclarının tüketiciye ürün aktarımında temelde iki kritik madde üzerinde yoğunlaşılmaktadır. Turizm ürünü manevi olarak düşünüldüğünde bu maddeler 'misafirperverlik ve vaat edilen turistik ürün hizmet'lerini kapsamaktadır. Bu hizmetler tüketilmeden önce değerlendirilemez. Misafirperverlik ve turistik ürün hizmeti, kişilerarasinda ürünü farklılaştıran, ürün değerini arttıran, duygusal riski azaltarak seyahat tüketicisinin karar vermesini kolaylaştıran unsurlardır (Litvin, Goldsmith, ve Pan, 2008).

Her seyahat tüketicisi farklıdır ve bundan ötürü herkesin farklı beklentileri bulunmaktadır. Söz konusu turistik ürünü satın alan tüketicilerin çeşitli web platformlarında yaptıkları e-WOM yorumları bulunmaktadır. Kullanıcıların seyahat deneyimlerini paylaşması, tavsiyeler yapması ve yapılan yorumların duygulara hitap etmesi e-WOM'u diğer bilgilerden daha güvenilir kılmaktadır. Bu bağlamda, e-WOM'un hızı, kolaylığı ve herhangi bir ticari kuruluş tarafından tutundurma çabasının olmayışından ötürü bilgi aktarımin en güvenilir yöntemlerinden biri konumuna getirmektedir. Geleneksel 
işletme ve tüketici (B2C) strateji anlayışını değiştiren elektronik ağızdan ağıza iletişim (e-WOM) tüketicinin satın alma niyetini ve önerilen ürünü satın alma olasılığını en üst düzeye çıkarmaktadır (Carmen, Burgess, Buultjens, ve Cox, 2009).

Seyahat tüketicisinin satın alma karar sürecinin beş temel aşamasında eWOM'un rolü Tablo 2'de detaylı gösterilmektedir;

\section{Tablo 3. E-WOM Ve Satın Alma Karar Süreci Aşamaları}

\begin{tabular}{ll}
\hline Satın Alma Karar Süreci Aşamaları & e-WOM Temas Noktalarına Örnekler \\
\hline Problem / İhtiyacın Belirlenmesi & $\begin{array}{l}\text { Dış uyaranlar - Web sitelerindeki reklamlar, kişileş- } \\
\text { tirmeler ve tavsiyeler }\end{array}$ \\
Bilgi arama & $\begin{array}{l}\text { Arama motorları, sosyal medya, ürün, web siteleri, } \\
\text { e-pazarlamacılar }\end{array}$ \\
Seçeneklerin Değerlendirilmesi & $\begin{array}{l}\text { Karşlaştırma seçeneğine sahip web siteleri, geri bil- } \\
\text { dirim için sosyal medya, çevrimiçi yorumlar, web } \\
\text { sitelerinin derecesi }\end{array}$ \\
Satın Alma Kararı & $\begin{array}{l}\text { Kanallar (e-ticaret siteleri) sosyal medya üzerinden } \\
\text { görüs ve geri bildirim }\end{array}$ \\
Satın sonrası davranış & $\begin{array}{l}\text { Siteleri inceleme, sosyal medya, çevrimiçi derece- } \\
\text { lendirme ve incelemeler, satın alınan ürünün site- } \\
\text { sinden veya sosyal medya üzerinden geri bildirim }\end{array}$ \\
\hline
\end{tabular}

Kaynak: Mishra, A., ve S.M.Satish. (2016). eWOM: Extant Research Review and Future Research Avenues. The Journal of Decision Makers.

Çevrimiçi incelemeler, kişilerarası etkileşim tutumlarını ve satın alma kararlarını etkilemektedir (Litvin, Goldsmith, ve Pan, 2008). Yapılan araştırmalar tüketicilerin negatif yorumlara inanmaya yönelik olduğunu göstermektedir. Lee, Park, ve Han (2006) ‘nın Güney Kore’de 248 üniversite öğrencisi üzerine yapılan olumsuz çevrimiçi tüketici incelemelerinin ürün tutumu üzerindeki etkilerini araştırmıştır. Basit bir negatif yorumun tüketicilerin tutumunu etkileyebilmesi ile birlikte pozitif yorumlardan daha etkili olduğu bulunmuştur. Chen ve Xu (2015), Tripadvisor seyahat uygulamalarından rastgele seçilen 1651 tüketicinin çevrimiçi davranışlarını içeren bir örnek toplamıştır. Yapılan araştırma e-WOM'un sanal topluluklar üzerindeki argüman kalitesinin (marka isimleri ve ürün özellikleri açısından) ve kaynak güvenilirliğinin eWOM'un etkisi ile önemli ölçüde ilişkili olduğu belirtilmiştir. O'Connor 
(2010) 'ın araştırmasında ise, İngiltere' deki Londra pazarı için Tripadvisor sitesinden rastgele seçilen 100 otelden oluşan bir örnek kullanarak içerik analizi tekniği ile incelenen yorumlar memnuniyet ve memnuniyetsizliğin ortak nedenlerini belirlemek için kullanılmıştır. Araştırmada siteyi ziyaret edenlerin sayısı ve yapılan puan derecelendirmeleri de göz önünde bulundurulmuştur. Araştırmaya göre çıkan rakamlar misafir deneyimini şeffaf hale getirmektedir ve incelemelerin potansiyel olarak seyahat tüketicilerinin kararları üzerinde etkisi olduğu belirtilmiştir.

\section{Araştırmanın Amacı}

$\mathrm{Bu}$ araştırmanın temel amacı, Uludağ'ı ziyaret eden yerli ve yabancı turistlerin o bölgede faaliyet gösteren 4 ve 5 yıldızlı konaklama işletmeleri hakkındaki olumsuz görüşlerini belirlemek ve bu görüşlerden yola çıkarak işletmelere öneriler sunmaktır.

\section{Araştırmanın Önemi}

$\mathrm{Bu}$ araştırma, bu alanda Uludağ destinasyonunda yapılmış ilk detaylı çalışma olması bakımından önemlidir. Bu çalışma, çevrimiçi incelemelerin ve yanıtların etkilerini araştırarak otel pazarlaması ve sosyal medya literatürüne katkıda bulunmaktadır.

\section{Araştırmanın Yöntemi}

Araştırmanın amacı doğrultusunda nitel yöntemlerinden içerik analizinden yararlanılmıştır. İçerik analizi Tavşancl ve Aslan'a (2001) göre, “metodolojik araç ve teknikler bütünü, kontrollü yorum yapma, nesnel, sistematik ve nicel yollardan betimleme, önceden belirlenmiş ölçütlere göre inceleme, anlam ç1karma, açık talimatlara göre nicelleştirme işlemi, niteli nicele dönüştüren bir işlem, kavramların ölçülmesi ve belirli bir anlam çıkarılması için kategorilere ayırma" olarak tanımlanmaktadır

Bir çözümleme yöntemi olarak adlandırılan içerik analizinde amaç, büyük miktardaki metinleri sözel, yazılı ve diğer materyalleri nesnel ve sistemsel olarak kategorilere dönüştürmektedir. İçerik analizinde esasında yapılan işlem, elde edilen verileri problem ve amaç doğrultusunda sınıflandırmasıdır. 
Bu işlem büyük miktardaki bir metnin verilerini azaltarak anlamlandırma sürecinde yardımcı olan bir araçtır (Erlingsson \& Brysiewicz, 2017).

\section{Araştırmanın Kapsam ve Sınırlılıkları}

Bu araştırmanın kapsamında www.tripadvisor.com isimli tatil deneyimi yorumlama web sitesi incelenmiştir. Söz konusu web sitesinde yer alan ve Bursa iline bağlı Uludağ kayak merkezinde bulunan konaklama işletmeleri için yazılan olumsuz yorumlar değerlendirmeye alınmıştır.

Araştırmanın sınırlılıkları;

- Zaman problemi,

- Tripadvisor.com web sitesinde ülke genelinde çok sayıda otel işletmesi yer almasl,

- Sadece bir otel işletmesinin bile sayısız kullanıcı yorumlarına sahip olmasindan dolayı sadece Uludağ bölgesindeki 4 ve 5 yıldız oteller örnekleme dahil edilmiştir.

\section{Ana kütle ve Örneklem}

Araştırmanın ana kütlesini www.tripadvisor.com web sitesindeki Uludağ' da bulunan 4 ve 5 yıldızlı konaklama işletmeleri hakkındaki yorum ve derecelendirmeler oluşturmaktadır. Tripadvisor, kullanıcılarının en iyi şekilde seyahat planlaması yapmasına yardımcı olan çevrimiçi bir seyahat araştırma şirketidir. Amerika Birleşik Devletleri'nde 2000 yılında kurulmuş olan "Tripadvisor" seyahat web sitesi, Çin de dahil olmak üzere 49 pazarda ve 28 dilde hizmet vermektedir. Tripadvisor, her ay 500 milyona yakın ziyaretçi sayısı ile seyahat tüketicilerine yardımcı olmaktadır. Restoranlar, oteller, kiralık tatil yerleri ve turistik yerler için sekiz milyondan fazla listeyi kapsayan yaklaşık 730 milyon kullanıc yorumuna sahip dünyanın en büyük seyahat bilgi platformudur (S.Lock, 2019). Gretzel tarafından yapılan çalışmaya göre, Tripadvisor kullanıcılarının otellerini seçmeyi ve "nerede kalınabileceğini" $(\% 77,9)$ e-WOM'a danışmaktadır. Ayrıca Gretzel çalışmasında, arama motorunda en çok tekrarlanan web sitesinin "Tripadvisor.com" olduğunu belirtmiştir. Bu bağlamda konaklama işletmelerine yönelik araştırmalarda seyahat tüketicilerin çevrimiçi yorum platformlarında "Tripadvisor" sitesine yönelmeleri gerekmektedir (Gretzel ve Yoo, 2008). Ayeh ve diğerleri (2013) Singapur'da 661 
seyahat tüketicisine online anket kullanarak bir araştırma yapmışlardır. Çevrimiçi gezginlerin UGC kaynaklarının tutum ve niyetleri nasıl etkilediğini incelemek güvenilirlik algıları ölçülmüştür. Katılımcıların çalışılan fenomeni net bir şekilde anlamalarını sağlamak için TripAdvisor'daki otellerin kullanıcı tarafından oluşturulan incelemelerine yönlendirilmiştir. Yapılan çalışmada Tripadvisor kaynak güvenirliliğinin tutum üzerindeki etkisinde önemli derecede destek bulunmuştur.

Araştırmada örneklem seçilirken, TripAdvisor'ın otel sınıfı değerlendirmesinde 4 ve 5 yıldıza sahip olan 8 adet otel değerlendirme kapsamına alınmiştır. Ayrıca bu 8 otel için yazılan 317 adet Türkçe ve 25 adet İngilizce olmak üzere toplamda 342 yorum incelenmiştir. Söz konusu bu 342 otel işletmesinde puanlama değerleri rakamsal olarak 3(ortalama), 2 (zayıf) ve 1 (berbat) olarak belirtilmektedir. Yorumlar genel olarak 2015-2019 arasına aittir.

\section{Veri Toplama Yöntemi}

Araştırmada, veri toplama aracı olarak döküman analizi yönteminden yararlanılmıştır. Bu çalışmada veriler Tripadvisor web sitesinde oluşturulan çevrimiçi tüketici yorumlanı kullanılarak toplanmıştır. Verilerin elde edildiği yorumlar 2015 yılı Ağustos ayından 2019 yılı Mart ayına kadarki dönem arasından seçilmiştir. TripAdvisor web sitesinde bir konaklama işletmesiyle ilgili yorum yazan kişinin cinsiyeti, milliyeti ve yorumu yazdığı tarih görülebilmektedir. Ayrıca, kişinin işletmeye verdiği puan ile detaylı yorumuna ulaşmak da mümkündür. Veriler 1-31 Aralık 2019 tarihleri arasında toplanarak analiz edilmişlerdir.

\section{Bulgular}

Tablo 4. Demografik Özellikler

\begin{tabular}{|c|c|c|}
\hline \multirow{2}{*}{$\begin{array}{l}\text { Yerli Kullanıcıların } \\
\text { Cinsiyetleri }\end{array}$} & Cinsiyeti Belirlenemeyen: 67 & \multirow{2}{*}{$\begin{array}{l}\text { Yerli Yorum Sayısı: } \\
317\end{array}$} \\
\hline & Erkek: 139 & \\
\hline \multirow{2}{*}{$\begin{array}{l}\text { Yabancı Kullanıcıların } \\
\text { Cinsiyetleri }\end{array}$} & Cinsiyeti Belirlenemeyen: 5 & \multirow{3}{*}{$\begin{array}{l}\text { Yabanc1 Yorum } \\
\text { Sayıs1: } 25\end{array}$} \\
\hline & Erkek: 14 & \\
\hline \multirow[t]{2}{*}{ Milliyeti } & \multirow{2}{*}{$\begin{array}{l}1 \text { Hollanda'lı, } 1 \text { Singapur'lu, } 6 \text { İngiliz, } 3 \text { Birleşik Arap Emir- } \\
\text { likleri vatandaşı, } 2 \text { Fransız, } 1 \text { Alman, } 2 \text { Suudi Arabistan'lı, } \\
1 \text { Katar'lı, } 2 \text { Kuveyt'li, } 1 \text { Çin'li, 1'i Irak, } 2 \text { Avustralya'll, } 1 \\
\text { Hint'li, } 1 \text { Prag'll }\end{array}$} & \\
\hline & & $\begin{array}{l}\text { Toplam Yorum } \\
\text { Sayıs1: } 342\end{array}$ \\
\hline
\end{tabular}




\section{Konaklama İşletmeleriyle İlgili Yazılan Yorumlara İlişkin Bulgular}

Uludağ'da faaliyet gösteren 4ve 5 yıldızlı TripAdvisor'daki konaklama işletmeleriyle ilgili ortalama (3), zayıf (2) ve berbat (1) değerlendirmesi yapan kullanıcıların yorumları 8 farklı kriter altında değerlendirilmiştir. Bu kriterler; odalar, yiyecek-içecek, personel, fiyat/fayda, yönetim, atmosfer, hizmet, otelin özellik ve imkanlarıdır.

Yapılan içerik analizi sonucunda toplam 343 yorum toplanmıştır. Yorumların kriterlere göre ayırımına bakıldığında sırasıyla; "oda" kriteri ilk sırada yer alırken (f: 155), ikinci olarak "yiyecek-içecek" ile ilgili değerlendirmesi (f: 150) ve üçüncü sırada "personel" kriterinin olduğu (f:139), dördüncü sırada ise; "hizmet" (f: 91) bulunduğu, beşinci siradaki değerlendirmede ise; "atmosfer" (f: 73), ardından "otelin özellik ve imkanları" (f: 68) ve devamında "fiyat/fayda" (f: 53), son olarak "yönetim" (f: 22) şeklinde tespit edilmiştir.

Tablo 5. Yorumlarda en sik kullanılan kelimelerin frekansları

\begin{tabular}{|c|c|c|c|c|c|c|c|}
\hline Odalar & $\begin{array}{l}\text { Yiyecek- } \\
\text { içecek }\end{array}$ & Personel & Hizmet & Atmosfer & $\begin{array}{l}\text { Otelin Özellik } \\
\text { ve İmkanları }\end{array}$ & $\begin{array}{l}\text { Fiyat/ } \\
\text { Fayda }\end{array}$ & Yönetim \\
\hline $\begin{array}{l}\text { Kirli } \\
\text { n: } 40\end{array}$ & $\begin{array}{l}\text { Lezzet- } \\
\text { siz } \\
\text { n: } 19\end{array}$ & $\begin{array}{l}\text { İgisiz } \\
\text { n: } 39\end{array}$ & $\begin{array}{l}\text { Kötü } \\
\text { n: } 25\end{array}$ & $\begin{array}{l}\text { Gürültülü } \\
\text { n: } 20\end{array}$ & $\begin{array}{l}\text { Eski } \\
\text { n: } 24\end{array}$ & $\begin{array}{l}\text { Pahalı } \\
\text { n: } 20\end{array}$ & $\begin{array}{l}\text { Kötü } \\
\text { n: } 11\end{array}$ \\
\hline $\begin{array}{l}\text { Kötü } \\
\text { koku } \\
\text { n: } 18\end{array}$ & $\begin{array}{l}\text { Kötü } \\
\text { n: } 18\end{array}$ & $\begin{array}{l}\text { Kaba } \\
\text { n: } 27\end{array}$ & $\begin{array}{l}\text { Berbat } \\
\text { n: } 15\end{array}$ & $\begin{array}{l}\text { Soğuk } \\
\text { n: } 17\end{array}$ & $\begin{array}{l}\text { Aktivite yok } \\
\text { n: } 14\end{array}$ & $\begin{array}{l}\text { Çok pahalı } \\
\text { n: } 11\end{array}$ & $\begin{array}{l}\text { Çok Kötü } \\
\text { n: } 1\end{array}$ \\
\hline $\begin{array}{l}\text { Eski } \\
\text { n: } 25\end{array}$ & $\begin{array}{l}\text { Kalitesiz } \\
\text { n: } \mathbf{1 7}\end{array}$ & $\begin{array}{l}\text { Suratsiz } \\
\text { n: } 24\end{array}$ & $\begin{array}{l}\text { Rezalet } \\
\text { n: } 12\end{array}$ & $\begin{array}{l}\text { Kalabalık } \\
\text { n: } 12\end{array}$ & $\begin{array}{l}\text { Aktivite } \\
\text { Yetersiz } \\
\text { n: } 4 \\
\end{array}$ & $\begin{array}{l}\text { Değmez } \\
\text { n: } 9\end{array}$ & $\begin{array}{l}\text { Rezalet } \\
\text { n: } 3\end{array}$ \\
\hline $\begin{array}{l}\text { Çok eski } \\
\text { n: } \mathbf{1 1}\end{array}$ & $\begin{array}{l}\text { Berbat } \\
\mathbf{n}: \mathbf{1 7}\end{array}$ & $\begin{array}{l}\text { Eğitimsiz } \\
\text { n: } 12\end{array}$ & $\begin{array}{l}\text { Yavaş } \\
\text { n: } 6\end{array}$ & $\begin{array}{l}\text { Çok } \\
\text { Kalabalık } \\
\text { n: } 6\end{array}$ & $\begin{array}{l}\text { Ortak Alan } \\
\text { Yetersiz } \\
\text { n: } 4 \\
\end{array}$ & $\begin{array}{l}\text { Kötü } \\
\text { n: } 7\end{array}$ & $\begin{array}{l}\text { Berbat } \\
\mathrm{n}: 2\end{array}$ \\
\hline $\begin{array}{l}\text { Soğuk } \\
\text { n: } 18\end{array}$ & $\begin{array}{l}\text { Çeşit az } \\
\text { n: } 15\end{array}$ & $\begin{array}{l}\text { Yetersiz } \\
\mathbf{n}: \mathbf{1 2}\end{array}$ & $\begin{array}{l}\text { Kalitesiz } \\
\text { n: } 5\end{array}$ & $\begin{array}{l}\text { Kötü Koku } \\
\text { n: } 11\end{array}$ & $\begin{array}{l}\text { Wifi Çekmiyor } \\
\text { n: } 13\end{array}$ & $\begin{array}{l}\text { Eş Değer } \\
\text { Değil } \\
\mathrm{n}: 4 \\
\end{array}$ & $\begin{array}{l}\text { ìlgisiz } \\
\text { n: } 2\end{array}$ \\
\hline $\begin{array}{l}\text { Çok S1- } \\
\text { cak } \\
\text { n: } 7\end{array}$ & $\begin{array}{l}\text { Rezalet } \\
\text { n: } 14\end{array}$ & $\begin{array}{l}\text { Terbiyesiz } \\
\text { n: } 7\end{array}$ & $\begin{array}{l}\text { Yetersiz } \\
\text { n: } 5\end{array}$ & $\begin{array}{l}\text { Havasiz } \\
\text { n: } 4\end{array}$ & $\begin{array}{l}\text { Kötü Pist } \\
\mathrm{n}: 2\end{array}$ & $\begin{array}{l}\text { Tatmin } \\
\text { edici Değil } \\
\mathbf{n} \mathbf{1}\end{array}$ & $\begin{array}{l}\text { Yetersiz: } \\
\text { n: } 1\end{array}$ \\
\hline $\begin{array}{l}\text { Havasız } \\
\text { n: } \mathbf{1 1}\end{array}$ & $\begin{array}{l}\text { Vasat } \\
\text { n: } 14\end{array}$ & $\begin{array}{l}\text { Saygisiz } \\
\text { n: } 6\end{array}$ & $\begin{array}{l}\text { Çok kötü } \\
\text { n: } 8\end{array}$ & $\begin{array}{l}\text { Kasvetli } \\
\text { n: } 1\end{array}$ & $\begin{array}{l}\text { Yetersiz pist } \\
\text { n: } 2\end{array}$ & $\begin{array}{l}\text { Yetersiz } \\
\mathbf{n}: \mathbf{1}\end{array}$ & $\begin{array}{l}\text { Terbiye- } \\
\text { siz } \\
\text { n: } 1\end{array}$ \\
\hline $\begin{array}{l}\text { Rutu- } \\
\text { betli } \\
\mathrm{n}: 4 \\
\end{array}$ & $\begin{array}{l}\text { Çok } \\
\text { Kötü } \\
\text { n: } 11\end{array}$ & $\begin{array}{l}\text { Canından } \\
\text { Bezmiş } \\
\mathrm{n}: 4 \\
\end{array}$ & $\begin{array}{l}\text { Hayal K1- } \\
\text { riklığı } \\
\text { n: } 7 \\
\end{array}$ & $\begin{array}{l}\text { Güvenli De- } \\
\text { ğil } \\
\text { n: } \mathbf{1}\end{array}$ & $\begin{array}{l}\text { Ortalama } \\
\mathrm{n}: 2\end{array}$ & & $\begin{array}{l}\text { Eksik } \\
\text { n: } 1\end{array}$ \\
\hline
\end{tabular}




\begin{tabular}{|c|c|c|c|c|c|}
\hline $\begin{array}{l}\text { Bakım- } \\
\text { siz } \\
\text { n: } 4\end{array}$ & $\begin{array}{l}\text { Orta- } \\
\text { lama } \\
\mathrm{n}: 10\end{array}$ & $\begin{array}{l}\text { Berbat } \\
\mathrm{n}: 3\end{array}$ & $\begin{array}{l}\text { Sifir } \\
\mathrm{n}: 3\end{array}$ & $\begin{array}{l}\text { Kaos } \\
\text { n: } 1\end{array}$ & $\begin{array}{l}\text { Hayal Kırıklı̆̆ } \\
\text { n: } 1\end{array}$ \\
\hline $\begin{array}{l}\text { Kullanış- } \\
\text { sız } \\
\mathrm{n}: 3\end{array}$ & $\begin{array}{l}\text { Fena De- } \\
\text { gil } \\
\text { n: } 9\end{array}$ & $\begin{array}{l}\text { Aşırı İlgi } \\
\text { n: } 1\end{array}$ & $\begin{array}{l}\text { Fena değil } \\
\mathrm{n}: 3\end{array}$ & & $\begin{array}{l}\text { Berbat } \\
\mathrm{n}: 1\end{array}$ \\
\hline $\begin{array}{l}\text { Küçük } \\
\text { n: } 4\end{array}$ & $\begin{array}{l}\text { Başarısız } \\
\mathrm{n}: 3\end{array}$ & $\begin{array}{l}\text { Rahatsiz } \\
\text { edici } \\
\text { n:1 }\end{array}$ & $\begin{array}{l}\text { Ortalama } \\
\text { n: } 2\end{array}$ & & $\begin{array}{l}\text { Kötü } \\
\text { n:1 }\end{array}$ \\
\hline $\begin{array}{l}\text { Karanlik } \\
\mathrm{n}: 3\end{array}$ & $\begin{array}{l}\text { Korkunç } \\
\mathrm{n}: 2\end{array}$ & $\begin{array}{l}\text { Vasat } \\
\mathrm{n}: 2\end{array}$ & & & \\
\hline $\begin{array}{l}\text { Berbat } \\
\mathrm{n}: 3\end{array}$ & $\begin{array}{l}\text { İdare } \\
\text { eder } \\
\text { n: } 1 \\
\end{array}$ & $\begin{array}{l}\text { Agresif } \\
\text { n: } 1\end{array}$ & & & \\
\hline \multicolumn{6}{|l|}{$\begin{array}{l}\text { Kalitesiz } \\
\mathrm{n}: \mathbf{2}\end{array}$} \\
\hline \multicolumn{6}{|l|}{$\begin{array}{l}\text { Kasvetli } \\
\mathrm{n}: 1\end{array}$} \\
\hline $\begin{array}{l}\text { Fena } \\
\text { değil } \\
\text { n: } 1\end{array}$ & & & & & \\
\hline
\end{tabular}

Yorumlar için yapılan inceleme sonucunda yukarıdaki tabloda belirtilen kriterlere ait değerlendirmelere ilişkin konaklama işletmeleri ilgili bazı ifadelerin dikkat çektiği görülmüştür. Çevrim içi içerik kullanıcıların konaklama işletmeleri ile ilgili yaşadıkları deneyimleri ifade etmek için kullandıkları kelime ve cümlelerde ön plana çıkanlar örnek olması bakımından aşağıda verilmiştir.

İşletmelerdeki rezerve edilen oda ilgili yorumlarda "kirli" olarak nitelendirilen yorumlarda: "Çoğu umumi tuvaletten daha kötü durumdaydı", "Duşlarda bırakın insanın yıkanmasının evcil hayvanimi bile yıkamam", "ilk yatağa yatmam ile rahatsızlanmam bir oldu", "pis ve içler acısı mikrop yuvası halılar", "lağım çukuru gibi bir odaya atıldı" ifadeleri; odaları "kötü koku" olarak nitelendirilen yorumlarda ise; "çözüm su giderine parfüm dökmekmiş bu otelde öğrendim", "tezek kokulu bir oda verdiler", "sigara sever otel" ifadeleri; odaları "eski" olarak nitelendirilen yorumlarda ise; "sene olmuş 2018, hala duş perdesi", "51 ekran tüplü televizyon", "otelin açıldığı tarihteki yataklar", "odamız resmen 40 yıl önce nasılsa, ayni öyle bırakılmıştı", "odalar fare yuvası gibi", "banyoda milâttan kalma bir perde", "fön makinası ilk icat edilenlerden" gibi ifadeler bulunmaktadır.

İşletmelerdeki sunulan yiyecek-içecek ile ilgili yorumlarda "lezzetsiz" olarak nitelendirilen yorumlarda: "lezzet yoksunu ana yemekler", "lezzetsiz tadı 
tuzu olmayan tost ve yağ çekmiş bir patates", "sıfir lezzeti olduğu gibi bir de içinden kıl çıkıyordu", "büfeyi zengin göstermek için yapılmış yemekler" ifadeleri; yiyecek-içecekleri "kötü" olarak nitelendiren yorumlarda ise; "kahvaltıda artanlar beş cayanda sunuluyor", "çay zift gibi", "Yemeklerden zehirlendik", "bir öğün de neredeyse sadece hindi eti ve türevleri vardı" ifadeleri; yiyecek-içecekleri "korkunç olarak nitelendirilen yorumlarda ise; "korkunç kurabiyeler, "korkunç, her gün resmen artık partisi yapılıyor" olarak ifade edilmiştir.

Konaklama işletmelerinde çalışan personel "ilgisiz" olarak nitelendirilen yorumlarda: "otelin hatası olan bir konuda sen kendin çöz", "bu donem böyle gibi saçma bir cevap alıyorsunuz", "çalışanlar mecburen çalışıyor havasında", "beni bekletip kendi cep telefonundan iş görü̧̧mesi yapması çok ilginçti", "suratınıza bakmyor.", "sizi sallamayan garsonlar" ifadeleri; personeli kaba olarak nitelendirilen yorumlarda ise; "gece müdürü kaba bir şekilde kardeşim yangın tüpünü sen mi sıktın", "yemeklerinizi daha yemeden önünüzden alyyorlar", "çalışanları birbirine girdi ayırabilen kimse yoktu jandarmalar oteli bastı", "bir şey sormaya çekinirsiniz", size küfür etme cesaretini bile gösterebiliyor", "Otele sicil kaydınz temiz giriyorsunuz katil olarak geri çıkıyorsunuz", "garson parmağını soktu buz kabına "aaa evet yıkansa çıkar." dedi", karşılama niye geldiniz der gibiydi", "personelin " bitse de gitsek" dediğini duydum "gibi ifadeler dikkat çekmiştir.

Hizmet kriterini "kötü" olarak değerlendirilen yorumlarda: "saçma sapan bir hizmet mantı̆̆ $ı$ "dandik disko", "otel için bu kadar değersizsiniz"," tesis güzel zihniyet kötü"," verdiğiniz 5 yıldızh otelde gibi değil de toplama kampinda gibi hissediyorsunuz", "5 yıldızh otel de 3 yıldizh otel hizmeti bile alamadık", "hiç bir insani değeriniz yok hiç bir şikayet hakkmız yok", "5 saattir duş alabilmek için su bekliyorum survivor misali", "bu kadar kötü pis iğrenç saygısız terbiyesiz otel görmedim" ifadeleri: "rezalet" olarak nitelendirilen yorumlarda ise; "tüm servis hizmetlerinde büyük rezalet", "böyle rezalet bir hizmet görmedim"," rezalet, hiç bir hizmet yok", "gecekondu rezaleti " gibi ifadeler yer almaktadır.

Atmosfer kriterini "gürültülü" olarak nitelendirilen yorumlarda: "kapıları yumruklayan ve herkesi uyandırmayı çalı̧̧an misafirler", "tüm bas ve müzik seslerini odanızda duyuyorsunuz", "gece gürültüden uyuyamadık bir görevli gelmedi", "bangir bangır müzikleri var", "gürültü içerisinde baş ağrısı ile oturmak zorundasınız", "oda izolasyonu sıfir yan odadaki bebek sabaha kadar sanki bizim odada ağladı" ifadeleri: "kötü koku" olarak belirtilen yorumlarda; "restaurantta girer girmez mide bulandırıcı bir koku yemek yedirmiyor", " restaurant üzeri açık olduğu için odalara yemek kokusu geliyor", "lobide ağır bir toz kokusu vardı", "korkunç bir sigara 
duman ve kokusu ile ani bir zehirlenme ", "otelin kapısından girer girmez aldığınız lağım kokusu" gibi ifadeler: "kaos" olarak belirtilmiş yorum ise; "otelde bir kaos ortamı hakim" "biz tatilimizin ikinci günündeyken oteli bastılar" ifadesi yer alırken "güvenli değil" şeklinde belirtilen yorumda ise "güvenli değil otel önünden ateş edip rastgele insanlar ölebiliyor, camlar kırıldı" gibi ifadeler de ön plana çıkmıştır.

Otelin özellikleri ve imkanları kriterini "eski" olarak nitelendirilen yorumlarda: "aksesuarlar, spa, restoran hepsi eskimiş artık kesinlikle yenilenmesi lazım", "otel çok eski güya yenilemişler yenileme anlayışları sadece mobilyaları değiştirmek", "artık lütfen oteli yenileyin"," otelin eski ve döküntülü̈̆̈̈nü size sadece bir fotoğrafla anlatmak yeterli", "döküntü bina", "survivor bir tatil yaşamak isteyenlere tavsiye ederim" ifadeleri: bu kriterde "aktivite yok" olarak nitelendirilen yorumlarda ise; "akşamları yapacak bir şey yok otelde sıkıldığınızda çıkıp yapabileceğiniz hiçbir şey bulunmamaktadır", " animasyon eğlence hiçbir şey yok", "zamanı geçirmek için aktivite yok"," bence gelirseniz otele ve programlarna güvenmeyin", "iskambil kağıdı dahi yok", "hava kötüyse otur orta yerinden çatla", "hiç bir aktivite yoktu", "akşam kesinlikle sıkıcı canlı müzik hiç bir aktivite yok "gibi ifadeler dikkat çekmiştir.

Konaklama işletmelerindeki fiyat/fayda kriterinde "pahalı" olarak nitelendirilen yorumlarda: "Kafalarına göre ücret tarifesi", "normalin dışında para veriyorsunuz", "kara basma parası alacaklar diye çok korktuk", ödediğimiz fiyatın karşılığın hizmet olarak alamadık", "yanmıza bol bol para alı", " tatiliniz tahmin ettiğinizden pahalıya mal olacak", "su içseniz para ödemek zorundasını!!" ifadeleri; fiyat/fayda değerini "kötü" olarak nitelendirilen yorumlar ise; "bu fiyata bu otel gerçekten inamilmaz derece de kötü, "iyi bir kayak değil bu fiyat/hizmet", "bir daha kesinlikle tercih etmem bu fiyata çok kötüydü" ifadeleri; "değmez" olarak nitelendirilen yorumlarda ise; "değmez Uludağ da ayn fiyata çok daha iyi oteller var", "verdiğiniz paraya kesinlikle değmez", "bu ücrete bunlar değmez kesinlikle gelmeyin", "verdiğiniz parayı otel hak etmiyor" gibi ifadeler dikkat çekmiştir.

Yönetim kriterini "kötü" olarak nitelendirilen yorumlarda: "bir otel bu kadar kötü işletilebilir", "bir sorunla karşılaştığınızda yöneticiler ortada yok", "otel yönetici konseptini gözden geçirmesi gerekiyor"," bu kadar güzel bir tesis ancak bu kadar kötü yönetilebilir", "yıllarn oteli ama bence iyi bir işletme müdürüne ihtiyacr var", "personel çok iyiler ama yönetime yazı!!", "otel, temel idareden yoksun" ifadeleri; yönetim değerini "berbat" olarak değerlendirilen yorumlar; "berbat ötesi, hayatımda böyle bir rezil otel ve işleten görmedim", "acilen yönetimin değişmesi gerekli. berbat ötesi" olarak ifade edilmiştir. 


\section{Sonuç ve Değerlendirme}

Konaklama işletmeleri, tüketicinin satın aldıktan sonra deneyimlediği bir hizmet olması ve turizmin gelişmesi ile doğrudan bağlantılı olan bir endüstridir. Misafirlerin ihtiyaçlarını karşılamak ve memnuniyetinin sağlanması hususunda konaklama işletmeleri büyük bir rol sahiplenmektedir. Konaklama işletmelerinin başarısı, kaliteli hizmet sunmalarına ve bu hizmeti verecek eğitimli personel bulundurmalarına bağlıdır. Verimlilik, her zaman konaklama işletmelerinin en önemli ve ilk adımını oluşturan ifade olmuştur. Otellerde verilen hizmetin kalitesi, fiyat/fayda dengesi, nitelikli personel ve otelin fiziki konumu da misafir memnuniyetini etkileyen önemli faktörlerdendir.

İncelemeler detaylı olarak ele alındığında konaklama işletmelerindeki fiyat/fayda dengesi hususunda misafirlerin diğer otellerin olanakları ile sık sık karşılaştırma yaptıkları tespit edilmiştir. Yapılan bu tespitlerde verilen hizmete göre istenilen ücretin pahalı olduğu ve işletmenin bu ücreti hak etmediği kullanıcılar tarafından belirtilmiştir. Ayrıca her şey dahil alınan paket içerisinde yemek dışında her şeyin; su dahil ücretli olduğu tarzında yorumlar bile yazılmıştır. Bunun yanı sıra; Uludağ bölgesindeki otellerin hemen hemen hepsinin eski olması, yenilenmemesi otelin hizmet memnuniyetini oldukça etkileyen unsurlardır. Otelin fiziki imkanlarının ve eğlencenin yetersiz kalarak gelen misafirlerin tatilleri sırasında yapacak etkinlik bulamaması da yorumlarda dikkat çekmiştir. Personel hususu, Uludağ otellerine gelen misafirlerin dikkatini çeken bir diğer önemli konudur. Yapılan değerlendirilmelerde hizmet veren personellerin restaurant, housekeeping, resepsiyon, kayak odası gibi farklı departmanlardan olduğu not edilmiştir. Ancak bu incelemeler az olması ile birlikte yazılan yorumlar çoğunlukla otelin çalışanlarını bir bütün olarak ele almaktadır. Çalışan personelin genel tavrında kaba, saygısız, ilgisiz, sorunları çözmek için herhangi bir uğraş vermeyen personelin yansıra; herhangi bir sorun karşısında yeterince eğitimli olmamaları ve çalışanların sayıca az ve yetersiz olması da önemli olumsuz yorumlar arasındadır.

Konaklama işletmeleri, web tabanlı pazarlamanın tam olarak nasıl kullanıldığını araştırmalıdır. Geleneksel pazarlama bağımlılığından çıkıp kanallarını yeni pazarlama stratejilerine dönüştürmelidir. Tüketicilerine ulaşmak için etkileşimli medya aracılığıyla iletişimlerini nasıl en üst düzeye çıkaracaklarını keşfetmeleri gerekmektedir. Otel hizmet ve ürünleri somut değildir. Seyahat tüketicileri yüksek miktardaki ürün incelemelerini büyük ürün satışları 
olarak düşünebilirler. Otel işletmelerinin ürün ve hizmetlerini satmak için potansiyel alıcılarını tespit edip onları teşvik etmeleri gereklidir. Otel işletmelerinin yönetimleri, misafirleri çevrimiçi olarak olumlu müşteri yorumları oluşturmaya teşvik etmelidir. Chan ve Guillet (2011)' deki araştırmasında, otellerin müşteriler ile iyi ve samimi ilişki kurmalarını sağlamasına rağmen müşterileri ile etkileşim kurmanın bir yolu olarak sosyal medyadan tam olarak yararlanmadıklarına değinmiştir. İşletmelerin e-WOM reklamcılığı verimli bir pazarlama aracı olarak kullanabilmeleri için seyahat tüketicilerinin otel ürün ve hizmetleri hakkındaki beklentilerini anlamaları gerekir. eWOM'daki bileşen ve özellikler bu anlamda işletmelere büyük bir firsat yaratmaktadır.

Otellerin gelecekte başarılı olabilmesi için sosyal ağ kullanıcıları tarafından oluşturulan içerik kavramlarını etkili bir şekilde benimsemesi ve yararlanmaya çalışması gerekmektedir. Konaklama işletmeleri, daima kendi aralarında yoğun bir rekabet halindedir. Yöneticilerin, e-WOM incelemelerini dikkate alması pazarda üstünlük elde etmesini sağlayabilir ve bu da rekabet stratejilerinin gelişmesinde önemli bir kaynak olabilir. Otel işletmelerinin web sitelerindeki misafir yorumlarına çevrimiçi olarak yanıt vermelerinin, otel odalarının reel satışlarıyla olumlu bir şekilde ilişkili olduğunu öne sürülmüştür (Zhang, Ye, Law, ve Li, 2010). Bu durumda, işletmelerin müşteri şikayetlerine hızlı ve ilgili dönüş yapmaları müşteri memnuniyetini ve onların tekrar satın alma niyetlerini arttırdığını söyleyebiliriz. e-Wom, işletmeler için pazarlama maliyetlerini azaltır ve turizm pazarında olumlu bir itibar oluşturmaya katkıda bulunur.

"Marketingsherpa" tarafindan yapılan bir ankette, tüketicilerin sosyal medya aracılığıyla yorumlar yapmaları ve tartışmalarının işletme için marka hedeflerine ulaşmak, itibar oluşturmak ve farkındalığı artırmak hususunda etkili bir araç olduğu belirtilmiştir (Wang ve Rodgers, 2011). Bu görüşü destekleyen bir diğer çalışma ise; Kim, Lim \& Brymer (2014) Amerika'da uluslararası bir otel zinciri şirketinin desteği ile işletmeye bağlı faaliyet gösteren 128 otel ele alınarak yapılan araştırmada, otellerin 12 aylık sosyal medya kanallarındaki (Tripadvisor, Priceline, Hotels.com, Expedia and Yelp.online) olumsuz çevrimiçi incelemeleri gözlemlenmiştir. Araştırmada çevrimiçi seyahat siteleri aylık gözlemlenerek otelcilerin özellikle negatif yorumlardaki tutumu ve otel performans etkisi değerlendirilmiştir. Otelcilerin negatif yorumlar karşısında başarı ve marka itibarı için öneriler verilmiştir. Sonuç olarak sosyal 
medyayı etkin kullanan işletmelerin başarılı olduğu belirtilmiştir. İşletmelerin olumsuz incelemelere karşı herhangi bir işlem yapmaması firmanın imaj ve itibarına zarar verebilir.

Bu çalışma, uygulama alanı kapsamında doğrudan ve dolaylı sınırlamaları mevcut olmasına rağmen litetatüre önemli katkılar sağlayabileceğine inanılmaktadır. Gelecekte yapılması planlanan benzer çalışmalar için dikkat edilmesi gereken hususlardan en belirgini elektronik ağızdan ağıza iletişim birçok veri ve yorum, içerik bulundurma özelliği ile geleneksel tutundurma çabasından ayrılmaktadır. Bundan dolayı seyahat tüketicisinin satın alma kararının ne yönde etkilendiği konusunda bilgiler sunmaktadır. e- Wom, turizm endüstrisinde turistik ürün ve hizmet kalitesini ölçme, seçim kriterlerinin sınıflandırılmasına yönelik katkılar sağlayabilecektir. 


\title{
EXTENDED ABSTRACT
}

\section{Investigation of Online Consumer Reviews of 4 and 5 Star Accommodation Enterprises Operating in Uludağ: A Content Analysis on "TripAdvisor.com"}

\author{
Azize Rana Arkadaş - Tuğrul Ayyıldız \\ Adnan Menderes University
}

Changing competition conditions, new consumer behavior types and especially web-based systems bring new models and growth in the current hotel market. Web 2.0 tools make life easier for users by having a wide variety of websites and applications that allow individuals to buy, sell, pay, browse, publish, and share. Web 2.0 tools refer to the practices of bringing individuals together through a social participation network and information sharing network. The tools, called Web 2.0, are expressed as "Tripadvisor, Booking, Lonely Planet, Flickr, blogs and other online social networking sites, etc."

It is a fact that organizations that run web-based organizations in a competitive market environment are now more successful than organizations that use a limited web base. These organizations present both verbal and visual information simultaneously with the market they offer the product, and they offer new opportunities to learn about the needs and opinions of their customers and interact with them in a direct and personalized way. In addition, the continuous sharing of the users' experiences as information provides productivity and up-to-date. As a result, web-based platforms also provide a source of feedback for the service providers on the improvements they should make.

In the tourism industry, the number of accommodation businesses and tourism business numbers is increasing day by day. E-WOM and web-based communication tools play a major role in changing the customer's current decision. The frequent use of Web 2.0 technologies in recent times has significantly contributed to tourism demand and supply, as well as accommodation businesses. Travel consumers depend on the opinions of other individuals while purchasing intangible products and services of accommodation businesses. Therefore, businesses should also encourage travel consumers to 
share positive content. This will contribute to the minimization of costs as well as broadening the marketing range.

Increasing confidence in the internet changes the choice perception of travel consumers. Thus, more research is needed on e-WOM. Shaping the behavior and attitudes of travel consumers can take place in e-WOM in many ways. Some of these are web-based viewing platforms, discussion forums, boycott Web sites. Web-based discussion boards, online communities and social networking sites create a more reliable environment for individuals for eWOM advertising. E-WOM in social media is an important type of e-WOM. For example; After people return from vacation, they want to share their personal experiences with their friends on online social networking sites (instagram, facebook, etc.). They share photos of many of their experiences, such as the hotels they vacation, restaurants they eat, events they attend, and talk about the details of their travels. In addition, thanks to e-WOM, people give advice about accommodation enterprises by writing neutral comments on consumer review evaluation sites such as 'how clean the hotel they are staying in, whether the hotel staff is polite, whether they like the swimming pool or not.'

The fact that the services offered by accommodation businesses to consumers consist of many elements changes the criteria that constitute guest satisfaction. Guest satisfaction is a very relative concept in practice. By evaluating user comments, new consumer behavior styles that make up guest experiences can be followed and kept up to date. Evaluating negative comments based on the comments of travel consumers on the Tripadvisor site will make a significant contribution to this area.

In this study, 4 and 5 star accommodation enterprises operating in Uludağ are based on the evaluation. A content analysis of low-rated comments which are in English and Turkish language on accommodation businesses on the website called "Tripadvisor", one of the social network platforms where users share their experiences and opinions about touristic products and services, was analyzed, and the negative opinions of local and foreign tourists about these businesses were analyzed. The enterprises included in the sample of the study were evaluated on 8 different basic criteria and the prominent dimensions of these dimensions were determined. 
When the evaluations carried out during the study were considered in detail, it was found that the guests frequently made comparisons with the facilities of other hotels regarding the price / benefit balance in the accommodation enterprises. In these determinations, it was stated by the users that the fee requested according to the service provided is expensive and the business does not deserve this fee. In addition, everything except food in the all-inclusive package; There have even been comments such as it is paid, including water. And also; The fact that almost all of the hotels in the Uludağ region are old and not renewed are factors that greatly affect the service satisfaction of the hotel. It is pointed that the hotel's physical facilities and entertainment were inadequate and the guests who came to the hotel could not find any activities to do during their holidays. The issue of staff is another important issue that attracts the attention of guests visiting Uludag hotels. In the evaluations made, it has been noted that the employees who are working in the hotels are from different departments such as restaurant, housekeeping, reception, ski room. In addition to the rude, disrespectful, indifferent staff who do not make any effort to solve the problems; The fact that they are not educated enough in the face of any problem and the number and inadequacy of the employees are among the important negative comments.

As a result in this study, in line with the negative comments written about the enterprises in the study, criteria have been determined and suggestions have been made to prevent problems.

\section{Kaynakça / References}

Almeida, F. (2012). Web 2.0 technologies and social networking security fears in enterprises. International Journal of Advanced Computer Science and Applications. 3(2), 152-156, Portugal.

Alrawadieh, Z., ve Demirkol, Ş. (2015). Konaklama işletmelerinde e-şikâyet yönetimi: İstanbul'daki beş yıldızlı oteller üzerinde bir çalışma. Nişantaşı Üniversitesi Sosyal Bilimler Dergisi, 3(1), 132-151.

Ayeh, J. K., Au, N., ve Law, R. (2013). "Do we believe in TripAdvisor?"examining credibility perceptionsand online travelers' attitude towardusing user-generated content. Journal of Travel Research, 52(4), 437-452.

Cantallops, A. S., ve Salvi, F. (2014). New consumer behavior: A review of research on eWOM and hotels. Spain. 
Carmen, Burgess, S., Buultjens, C. S., ve Cox, J. (2009). The role of user-generated content in tourists' travel planning behavior. 743-762.

Chan, N. L., ve Guillet, B. D. (2011). Investigation of social media marketing: How does the hotel industry in Hong Kong perform in marketing on social media websites? 345368.

Chen, Y., ve Xu, Y. (2015). Exploring the determinants of influential eWOM in virtual communities: An empirical study. Internatıonal Textıle And Apparel Associatın (Itaa) Annual Conference Proceedıngs, içinde (s. 1-3). Santa Fe, New Mexico.

Chui, J. B. (2010). The rise of the networked enterprise: Web 2.0 finds its payday. Mckinsey global institute.

Constantinides, E., ve J.Fountain, S. (2008). Web 2.0: Conceptual foundations and marketing issues. Journal of Direct, Data and Digital Marketing Practice, 9(3), 231-244.

Doğan, S. (2017). Otellere yönelik yapılan puanlama ve çevrimiçi yorumların değerlendirilmesine ilişkin Aksaray İlinde bir araştırma. Aksaray Ünivertesi İIBF Dergisi, 9(3), 27-36.

Ekiz, E., Khoo-Lattimore, C., ve Memarzadeh, F. (2012). Air the anger: investigating online complaints on luxury hotels. 96-106.

Erlingsson, C., ve Brysiewicz, P. (2017). A hands-on guide to doing content analysis. 9399.

Gretzel U., Yoo K.H. (2008) Use and Impact of Online Travel Reviews. In: O'Connor P., Höpken W., Gretzel U. (eds) Information and Communication Technologies in Tourism 2008. Springer, Vienna.

Gürkan, G. Ç., ve Polat, D. D. (2014). Ege ve Akdeniz Bölgesi'nde faaliyet gösteren resort konaklama işletmeleri hakkında yapılan şikayetler üzerine nitel bir araştırma. Seyahat ve Otel İsletmeciliği Dergisi/Journal of Travel and Hospitality Management, 11(2), 45-61.

Harrison-Walker, L. J. (2001). The measurement of word-of-mouth communication and an investigation of service quality and customer commitment as potential antecedents. Journal of Service Research, 4(1), 60-75.

Kim, W. G., Lim, H., ve Brymer, R. A. (2014). The effectiveness of managing social media on hotel performance. International Journal of Hospitality Management, 44, 165-171.

Lee, J., Park, D.-H., ve Han, I. (2006). The effect of negative online consumer reviews on product attitude: An information processing view. Electronic Commerce Research and Applications içinde (s.341-352). 
Levy, S. E., Duan, W., ve Boo, S. (2013). An analysis of one-star online reviews and responses in the Washington D.C.. Lodging Market. 49-63.

Litwin, S.W., Goldsmith, R.E. \& Pan, B. (2008). Ellectronic word-of mouth in hospitality and tourism management. Tourism Management, 29, 458-468.

Mauri, A. G., ve Minazzi, R. (2013). Web reviews influence on expectations and purchasing intentions of hotel potential customers. International Journal of Hospitality Management, 34, 99-107.

Mishra, A., ve S.M.Satish. (2016). eWOM: Extant Research review and future research avenues. The Journal of Decision Makers, 41(3), 222-233.

O'Connor, P. (2010). Managing a hotel's image on TripAdvisor. Journal of Hospitality Marketing $\mathcal{E}$ Management, 19(7), 754-772.

S.Lock. (2019, October 8). TripAdvisor: Statistics $\mathcal{E}$ facts. Statista https://www.statista.com/topics/3443/tripadvisor/ adresinden alındı

Silverman, G. (2011). The secrets of word-of- mouth marketing. New York, USA: AMACOM.

Sparks, B. A., ve Browning, V. (2010). Complaining in cyberspace: The motives and forms of hotel guests' Complaints. Journal of Hospitality Marketing $\mathcal{E}$ Management, 19(7), 797-818.

Sunmak, M. E., Sunar, H., ve Coşkuner, M. (2017). Otel seçiminde online müşteri deneyimlerine dayalı analitik hiyerarşi süreci yönteminin kullanılması: Booking.Com örneği. Internatıonal Congress On Cultural Heritage And Tourism içinde (s. 829-837).

Wang, Y., ve Rodgers, S. (2011). Electronic word of mouth and consumer generated content: From concept to application. 212-231. Austin,USA.

Westbrook, R. A. (1987). Product/consumption-based affective responses and postpurchase processes. Journal of Marketing Research ,24(3), San Francisco.

Zaman, M., Botti, L., ve Thanh, T. V. (2015). Weight of criteria in hotel selection: An empirical illustration. 132-138.

Zhang, Z., Ye, Q., Law, R., ve Li, Y. (2010). The impact of e-word-of-mouth on the online popularity of restaurants: A comparison of consumer reviews and editor reviews. 694-700.

Zheng, T., Youn, H., ve Kincaid, C. S. (2009). An analysis of customers' e-complaints for Luxury Resort properties. 37-41. 


\section{Kaynakça Bilgisi / Citation Information}

Arkadaş, A. R. ve Ayyıldız, T. (2020). Uludağ'da faaliyet gösteren 4 ve 5 yıldızlı konaklama işletmelerinin çevrimiçi tüketici yorumlarının incelenmesi: "TripAdvisor.com" üzerinden içerik analizi. OPUSUluslararası Toplum Araştırmaları Dergisi, 16(30), 2633-2658. DOI: 10.26466/opus.780219 